\title{
Phoyunnanin E Induces Apoptosis of Non-small Cell Lung Cancer Cells via p53 Activation and Down-regulation of Survivin
}

\author{
PREEYAPORN PLAIMEE PHIBOONCHAIYANAN ${ }^{1,2}$, NALINRAT PETPIROON ${ }^{2,3}$, \\ BOONCHOO SRITULARAK ${ }^{4}$ and PITHI CHANVORACHOTE ${ }^{2,3}$ \\ ${ }^{1}$ Department of Pharmacology, Faculty of Pharmacy, Rangsit University, Pathumthani, Thailand; \\ ${ }^{2}$ Cell-based Drug and Health Product Development Research Unit, ${ }^{3}$ Department of Pharmacology and Physiology, \\ and ${ }^{4}$ Department of Pharmacognosy and Pharmaceutical Botany, \\ Faculty of Pharmaceutical Sciences, Chulalongkorn University, Bangkok, Thailand
}

\begin{abstract}
Background/Aim: Lung cancer is by far the most common cause of cancer mortality, accounting for nearly $20 \%$ of all global cancer deaths. Therefore, potent and effective compounds for treatment of this cancer type are essential. Phoyunnanin E, isolated from Dendrobium venustum (Orchidaceae), has promising pharmacological activities; however, it is unknown if phoyunnanin E affects apoptosis of lung cancer cells. Materials and Methods: The apoptosis-inducing activity of phoyunnanin E on H460 lung cancer cells was investigated by Hoechst 33342, and annexin $V$-fluorescein isothiocyanate/propidium iodide staining. The underlying mechanism was determined via monitoring apoptosis-regulatory proteins by western blot analysis. The apoptotic effect of the compound was confirmed in H23 lung cancer cells. Results: Phoyunnanin E significantly induced apoptotic cell death of H460 lung cancer cells, as indicated by condensed and fragmented nuclei with the activation of caspase-3 and -9 and poly (ADP-ribose) polymerase cleavage. Phoyunnanin E mediated apoptosis via a p53dependent pathway by increasing the accumulation of cellular p53 protein. As a consequence, anti-apoptotic proteins including induced myeloid leukemia cell differentiation protein (MCL1) and B-cell lymphoma 2 (BCL2) were found to be significantly depleted, while pro-
\end{abstract}

Correspondence to: Associate Professor, Dr. Pithi Chanvorachote, Department of Pharmacology and Physiology, Faculty of Pharmaceutical Sciences, and Cell-based Drug and Health Product Development Research Unit, Chulalongkorn University, Phatumwan, Bangkok 10330, Thailand. Tel: +662 2188344, Fax: +662 2188340, e-mail: pithi.c@chula.ac.th,pithi_chan@yahoo.com

Key Words: Phoyunnanin E, Dendrobium venustum, apoptosis, lung cancer. apoptotic BCL-2-associated X protein $(B A X)$ protein was upregulated. Furthermore, it was found that expression of an inhibitor of apoptosis, survivin, markedly reduced in response to phoyunnanin E treatment. The apoptosis-inducting effect was also found in phoyunnanin E-treated H23 lung cancer cells. Conclusion: These results indicate the promising effect of phoyunnanin $E$ in induction of apoptosis, that may be useful for the development of novel anticancer agents.

Despite intense interest in development of novel anticancer strategies, systemic chemotherapy remains the fundamental treatment of choice for lung cancer. Lung cancer is among the most common cancer types, with a very high mortality rate. The majority of all lung malignancies are non-small cell lung cancer (NSCLC). After systemic chemotherapeutic treatment, NSCLC frequently relapses, with median progression time at around 5-24 months (1). The major obstacle for successful lung cancer management is therapeutic resistance, especially in advanced-stage cancer (2), leading to the urgent need for novel, more effective drugs.

Apoptosis is the main mechanism by which chemotherapeutic drugs eliminate cancer cells (3). They often induce DNA adducts or a DNA-damage signal which trigger the apoptosis pathway via the activation of p53 protein (4). It is obvious that p53 can induce apoptosis by the specific trans-activation of target genes including B-cell lymphoma 2 (BCL2)-associated X (BAX) protein $(5,6)$. Moreover, expression of anti-apoptotic proteins, such as myeloid leukemia cell differentiation protein (MCL1) and BCL2, are reduced by p53 activation (5-7). The induction of pro-apoptotic proteins subsequently causes pores in the mitochondrial membrane to release cytochrome $c$ into the cytosol, caspase activation and poly (ADP-ribose) polymerase (PARP) cleavage, leading to apoptosis (8). 
Studies have indicated the important role of the antiapoptotic protein, survivin, in regulating drug resistance in cancers, including NSCLC $(9,10)$. From translational researches, it was found that the survivin may play a role in carcinogenesis and tumor progression (10). The nuclear expression of survivin in tumor tissues was also shown to predict prognosis in NSCLC (11). In advanced NSCLC treated with platinum-based chemotherapy, an elevated survivin level is associated with a poor prognosis (10). Such findings have led to development of survivin-targeted drugs, as these may benefit the treatment of resistant cancer. For instance, a survivin inhibitor FL118 was shown to improve drug sensitivity of resistant cancer cells and inhibit metastasis (12). Regarding the p53 pathway, it was shown that p53 activation led to survivin down-regulation by suppressing its expression at the transcriptional level (13). Reduction of survivin led to the dramatic induction of apoptosis through caspase- 9 and caspase-3-dependent mechanisms (14). Therefore, the induction of apoptosis via p53 activation accompanied by survivin suppression represents a better option to overcome resistance in cancer cells.

It is well recognized that natural products are among the most common sources for anticancer agents. Drug discovery has shifted toward identification of compounds overcoming the drug resistance problem (15-17). Dendrobium venustum Teijsm. \& Binn. (Orchidaceae) (Figure 1A) contains chemical constituents such as densiflorol B, phoyunnanin E, gigantol, batatasin III, phoyunnanin $\mathrm{C}$ and flavanthrinin. Densiflorol B and phoyunnanin $\mathrm{E}$ have been demonstrated to have strong anti-malarial activities (18). Phoyunnanin E was also found to exhibit anti-migratory activity on NSCLC cells and suppress epithelial-to-mesenchymal transition (19).

However, the effect of phoyunnanin $\mathrm{E}$ on apoptosis of cancer cells is not known. This study aimed to investigate the apoptosis induction activity of phoyunnanin E (Figure 1B) and its mechanisms in regulating apoptosis-related pathways in NSCLC cells. The results from this study may benefit the further development of this compound for anticancer agents.

\section{Materials and Methods}

Phoyunnanin E preparation. Phoyunnanin E (Figure 1B) was isolated from D. venustum (Figure 1A) as previously reported by Sukphan et al. (18). D. venustum was bought from Jatujak Market, Bangkok, in May 2012. Plant authentication was performed in comparison to herbarium specimens at the Department of National Park, Wildlife and Plant Conservation, Ministry of National Resources and Environment, Bangkok, Thailand. A voucher specimen (BS-DV-052555) was deposited at the Department of Pharmacognosy, Faculty of Pharmaceutical Sciences, Chulalongkorn University, Bangkok, Thailand. Entire dried and powdered plant (2 $\mathrm{kg}$ ) was macerated three times with 101 of methanol to obtain 164 $\mathrm{g}$ methanolic extract. The extract was subjected to vacuum-liquid chromatography on silica gel ( $n$-hexane EtOAc gradient) and 8 fractions $(\mathrm{A}-\mathrm{H})$ were taken. Fraction $\mathrm{G}(16.3 \mathrm{~g})$ was fractionated by column chromatography over silica gel eluting with a $\mathrm{CH}_{2} \mathrm{Cl}_{2}$ EtOAc gradient and 10 fractions were obtained. Phoyunnanin E (16 $\mathrm{mg}$ ) was obtained in fraction VII (2.2 g) as determined by thin-layer chromatography. The purity of phoyunnanin $\mathrm{E}$ was determined using nuclear magnetic resonance spectroscopy; extract with more than $95 \%$ purity was used in this study.

Cell culture and reagents. Human NSCLC H460 and H23 cells were obtained from the American Type Culture Collection (Manassas, VA, USA). The cancer cells were maintained in Roswell Park Memorial Institute (RPMI) 1640 medium supplemented with $10 \%$ fetal bovine serum (FBS), $100 \mathrm{U} / \mathrm{ml}$ penicillin, $100 \mu \mathrm{g} / \mathrm{ml}$ streptomycin, and $2 \mathrm{mM} \mathrm{L-glutamine.} \mathrm{Cells} \mathrm{were} \mathrm{cultured} \mathrm{in} \mathrm{a} 37^{\circ} \mathrm{C}$ humidified condition with $5 \% \mathrm{CO}_{2}$ and were routinely subcultured using a $0.25 \%$ trypsin solution with $0.53 \mathrm{mM}$ EDTA. RPMI 1640 medium, FBS, L-glutamine, penicillin/streptomycin, phosphatebuffered saline (PBS) and trypsin were purchased from GIBCO (Grand Island, NY, USA). Hoechst 33342 and bovine serum albumin (BSA) were purchased from Sigma Chemical, Inc. (St. Louis, MO, USA). Annexin V-fluorescein isothiocyanate/propidium iodide (FITC/PI) kit was obtained from Immunotools (Friesoythe, Germany). Antibodies directed against PARP, cleaved PARP, caspase-9, cleaved caspase-9, caspase-3, cleaved caspase-3, survivin, p-53, MCL1, BCL2, BAX and $\beta$-actin, and the respective secondary antibodies, were purchased from Cell Signaling (Danvers, MA, USA). For western blotting analysis, cells were collected after treatment with phoyunnanin $\mathrm{E}$ for $12 \mathrm{~h}$.

Cell viability assay. Cell viability was determined using a 3-(4,5dimethylthiazol-2-yl)-2,5-diphenyltetrazolium bromide (MTT) assay (20). In brief, lung cancer cells were seeded in the medium at a density of $1 \times 10^{4}$ cells/well in 96-well plates and treated with different concentrations of phoyunnanin $\mathrm{E}(0-100 \mu \mathrm{M})$ for $24 \mathrm{~h}$. The cells were then incubated with MTT solution $(400 \mu \mathrm{g} / \mathrm{ml})$ for $4 \mathrm{~h}$ at $37^{\circ} \mathrm{C}$. The supernatant solution was removed and $100 \mu$ dimethyl sulfoxide was added to dissolve the crystal formazan product. The resulting formazan intensities were analyzed by spectrophotometry at $570 \mathrm{~nm}$ using a microplate reader (Anthros, Durham, NC, USA). The cell viability (\%) was then calculated as the absorbance of phoyunnanin E-treated cells relative to that of untreated cells.

Nuclear staining assay. Cells were seeded in complete medium in 96-well plates at a density of $1 \times 10^{4}$ cells/well and treated with phoyunnanin $\mathrm{E}(0-50 \mu \mathrm{M})$ for $24 \mathrm{~h}$. After that, the cells were washed with PBS and incubated with $10 \mu \mathrm{g} / \mathrm{ml}$ Hoechst 33342 for $30 \mathrm{~min}$. Nuclear condensation and DNA fragmentation of apoptotic cells were scored using a fluorescence microscope (Olympus IX5) equipped with a DP70 digital camera system (Olympus, Tokyo, Japan).

Flow cytometry. Cells were plated in complete medium in 24-well plates at a density of $1.5 \times 10^{5}$ cells/well and treated with phoyunnanin $\mathrm{E}(0-50 \mu \mathrm{M})$ for $24 \mathrm{~h}$. Cells were harvested by trypsin, washed with PBS, and re-suspended in binding buffer. Single-cell suspensions were incubated with annexin V-FITC for $30 \mathrm{~min}$ in the dark at room temperature. PI was added and cells were then analyzed by flow cytometry (FACSort; Becton Dickinson, Rutherford, NJ, USA). 
A

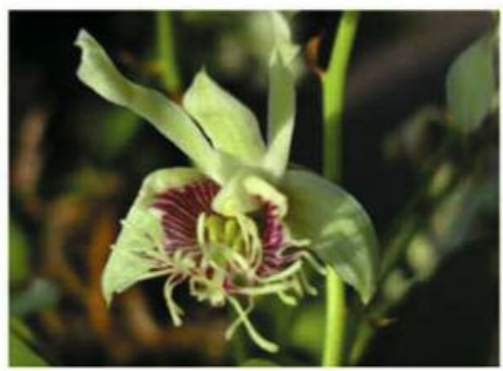

B<smiles>COc1cc(O)c2c(c1)CCc1cc(O)c(-c3c(OC)cc(O)c4c3Cc3cc(O)ccc3-4)cc1-2</smiles>

C

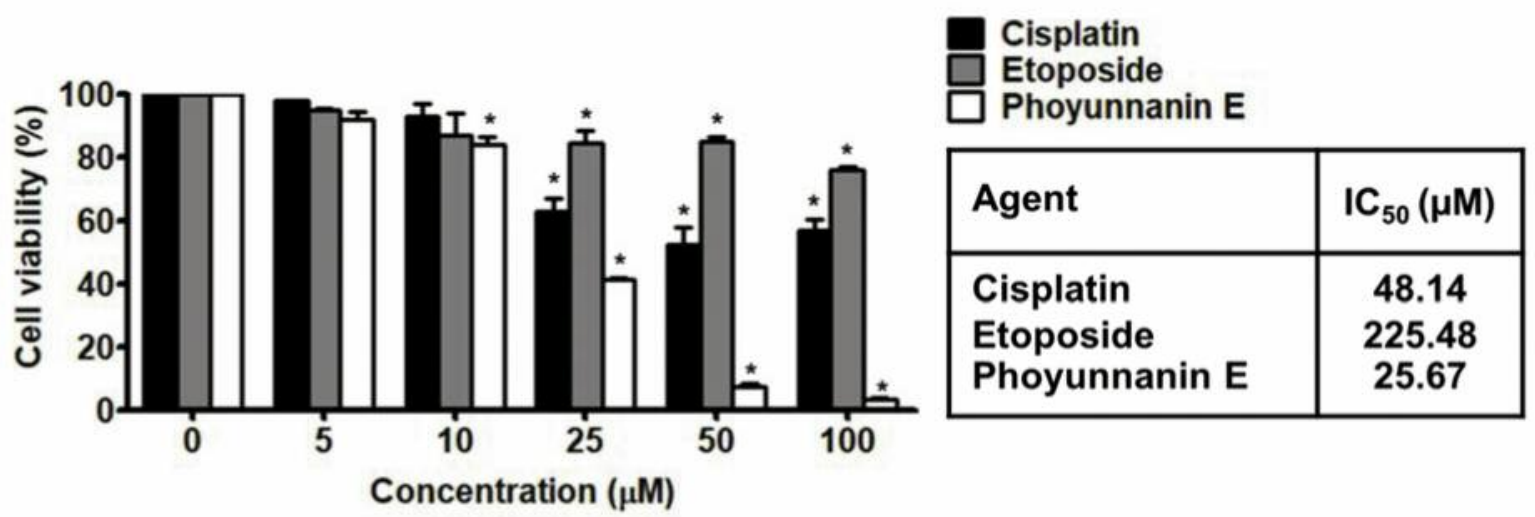

Figure 1. A: Dendrobium venustum Teijsm. \& Binn. (Orchidaceae). B: Structure of phoyunnanin E from D. venustum. C: Effect of phoyunnanin E on cell viability. Human Non-small cell lung cancer-derived $H 460$ cells were treated with phoyunnanin E, cisplatin, or etoposide for 24 h. Cell viability was analyzed by MTT assay. Data represent the mean $\pm S D(n=3)$. *Significantly different at $p<0.05$ versus non-treated control.

Western blotting. For western blotting analysis, cells (100,000 cells/well) were collected after treatment with phoyunnanin $\mathrm{E}$ $(5-50 \mu \mathrm{M})$ for $12 \mathrm{~h}$. Cells were harvested and lysed by lysis buffer [20 $\mathrm{mM}$ Tris- $\mathrm{HCl}(\mathrm{pH} 7.5), 1 \%(\mathrm{v} / \mathrm{v})$ Triton X-100, $150 \mathrm{mM}$ sodium chloride, $10 \%(\mathrm{v} / \mathrm{v})$ glycerol, $1 \mathrm{mM}$ sodium orthovanadate, $50 \mathrm{mM}$ sodium fluoride, protease inhibitor cocktail (Roche Molecular Biochemical, Mannheim, Germany) and $100 \mathrm{mM}$ phenylmethylsulfonyl fluoride] for $40 \mathrm{~min}$ on ice. The lysates were determined for their protein contents using a BCA protein assay kit (Pierce Biotechnology, Rockford, IL, USA). Equal amounts of protein from each sample were separated by sodium dodecyl sulfate polyacrylamide gel electrophoresis and transferred to $0.45 \mu \mathrm{m}$ nitrocellulose membranes (Bio-Rad, Hercules, CA, USA). The blots were blocked for $1 \mathrm{~h}$ with $5 \%$ (w/v) non-fat milk in TBST [ $25 \mathrm{mM}$ Tris- $\mathrm{HCl}(\mathrm{pH} 7.5), 125 \mathrm{mM} \mathrm{NaCl}$ and $0.1 \%(\mathrm{v} / \mathrm{v})$ Tween 20] and incubated with primary antibodies at $4{ }^{\circ} \mathrm{C}$ overnight. After three washes in TBST, the membranes were incubated with horseradish peroxidase (HRP)-conjugated secondary antibodies for $2 \mathrm{~h}$ at room temperature. Finally, protein bands were detected using an enhancement chemiluminescence substrate (Supersignal West Pico; Pierce, Rockford, IL, USA) and quantified using the analyst/PC densitometry software package (Bio-Rad).

Statistical analysis. All data from three or more independent experiments are presented as means \pm standard deviation (SD). Multiple comparisons for significant differences between multiple groups were performed using analysis of variance (ANOVA), followed by individual comparisons with Scheffe's post-hoc test at the $p<0.05$ significance level.

\section{Results}

Effect of phoyunnanin $\mathrm{E}$ on the viability of H460 human NSCLC cells. We examined the viabilities of H460 lung cancer cells treated with phoyunnanin E. The cells were incubated with 0-100 $\mu \mathrm{M}$ phoyunnanin $\mathrm{E}$ for $24 \mathrm{~h}$ and the respective cell viabilities were determined by MTT assay. For comparison, the widely prescribed chemotherapeutic drugs for the treatment of lung cancer, cisplatin and etoposide, were used at the same concentrations $(0-100 \mu \mathrm{M})$. The results indicated the potential of phoyunnanin $\mathrm{E}$ in mediating cytotoxicity to lung cancer cells as its half-maximal inhibitory concentration $\left(\mathrm{IC}_{50}\right)$ value was significantly lower than those of cisplatin and etoposide (Figure 1C). A significant decrease in cell viability was observed in cells treated with concentrations of phoyunnanin $\mathrm{E}$ of $10 \mu \mathrm{M}$ or more, whereas cisplatin and etoposide caused significant toxic to the cells at $25 \mu \mathrm{M}$ or more.

Apoptosis induction effect by phoyunnanin E. In order to examine the apoptosis-inducing effect of phoyunnanin E, cells 
A

Phoyunnanin E $(\mu \mathrm{M})$

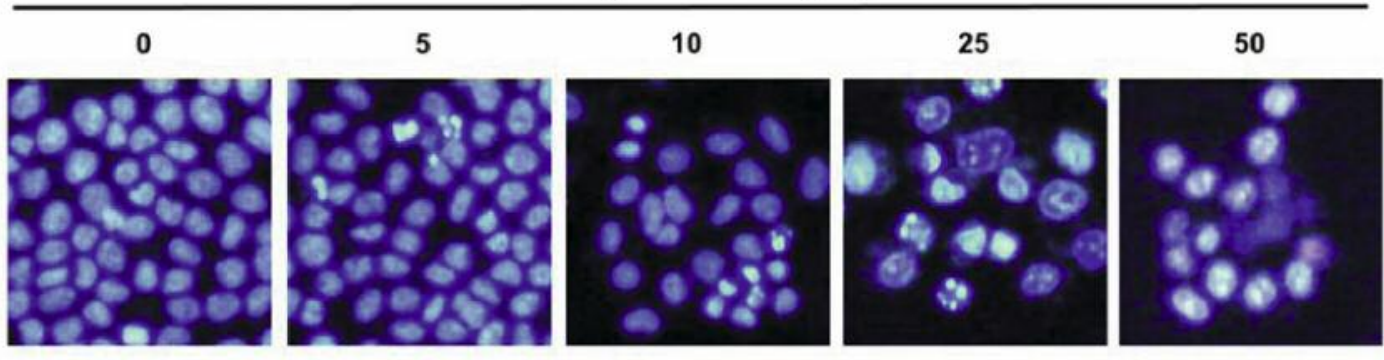

B

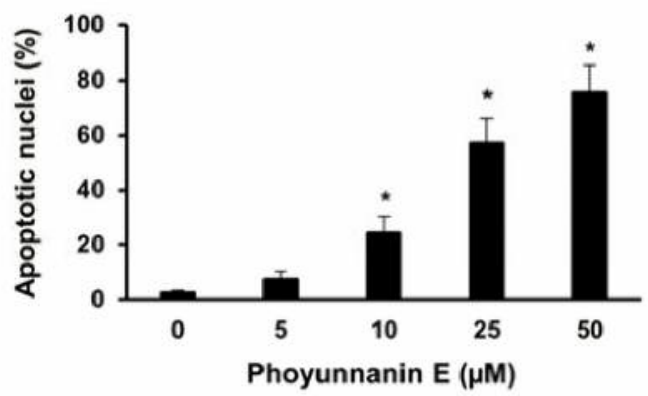

C

Phoyunnanin E $(\mu \mathrm{M})$

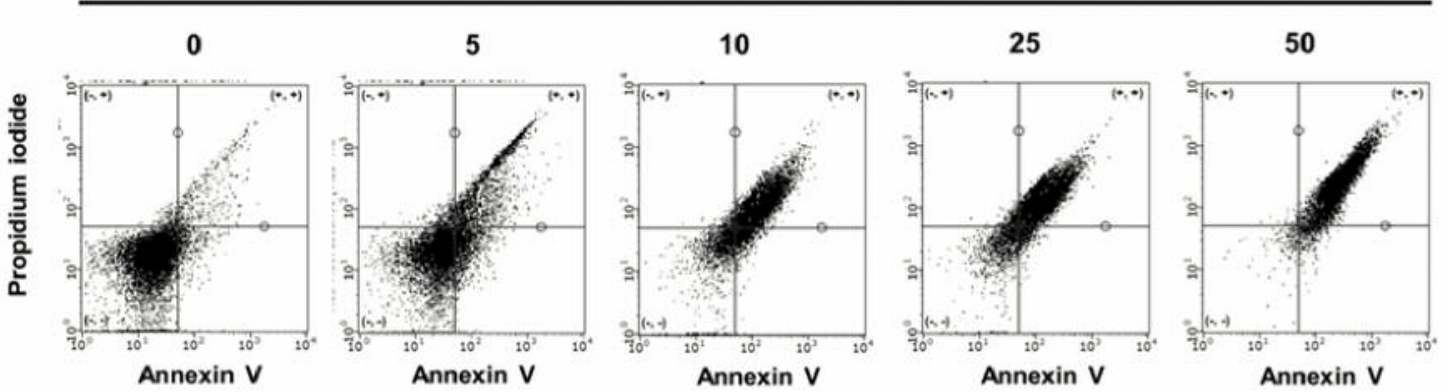

D

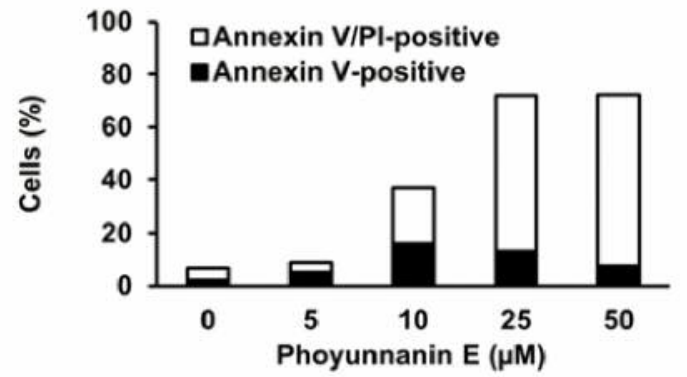

Figure 2. Apoptosis induction by phoyunnanin E. A: 4460 cells were treated with phoyunnanin E for 24 h. Apoptotic cell death after phoyunnanin E treatment was examined by Hoechst 33342 staining. B: The percentage of apoptotic nuclei in phoyunnanin E-treated cells was quantified. C: The apoptotic and necrotic cells were determined by annexin V-fluorescein isothiocyanate and propidium iodide (PI) staining and detected by flow cytometry after phoyunnanin E treatment. D: Percentages of annexin-V-positive and annexin-V/PI-positive cells were analyzed. Data represent the mean $\pm S D(n=3)$. *Significantly different at $p<0.05$ versus non-treated control. 
A

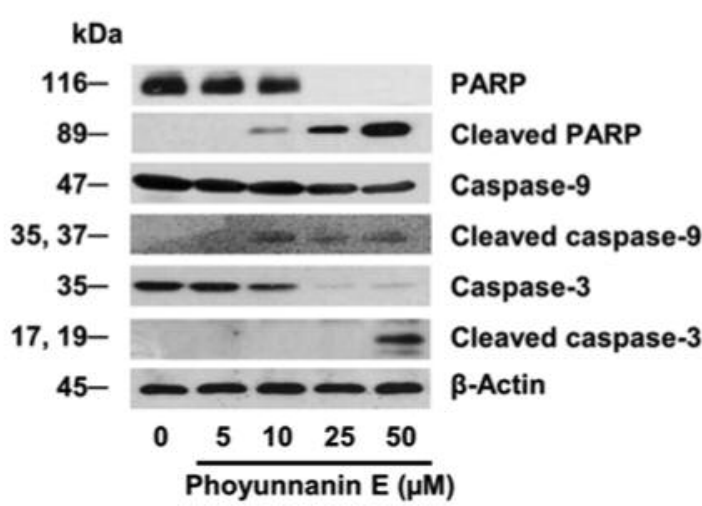

B
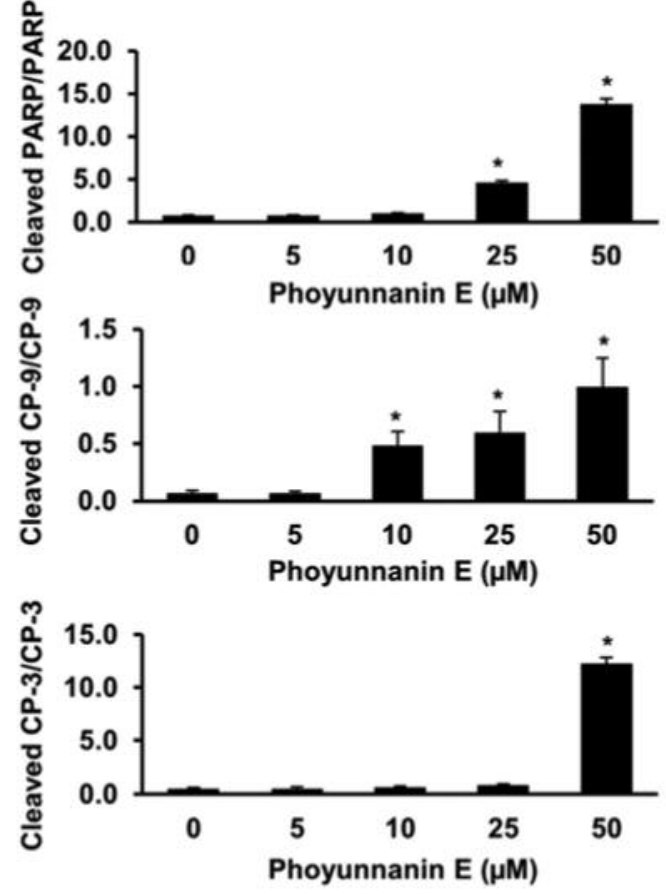

Figure 3. Phoyunnanin E activates apoptosis-associated proteins. H460 cells were treated with phoyunnanin E for 12 h. A: The expression levels of poly (ADP-ribose) polymerase (PARP), cleaved PARP, caspase-9, cleaved caspase-9, caspase-3, and cleaved caspase-3 proteins in H460 cells were determined by western blotting. B: Relative protein levels were quantified by densitometry. Data represent the mean \pm SD ( $n=3)$ * Significantly different at $p<0.05$ versus non-treated control.

were treated with phoyunnanin $\mathrm{E}$ and apoptotic cell death was investigated by Hoechst 33342 staining assay. The results indicated that $10-50 \mu \mathrm{M}$ of phoyunnanin E caused a significant increase in the number of cells with condensed or fragmented nuclei compared with non-treated control cells (Figure 2A and B). To confirm the apoptosis induction effect of phoyunnanin $\mathrm{E}$, the occurrence of apoptotic and necrotic cells was investigated by annexin V-FITC/PI staining. Flow cytometric analysis indicated that both annexin V-FITC-positive cells (early apoptotic cells) and annexin V-FITC/PI-positive cells (late apoptotic cells) appeared in cells treated with 10-50 $\mu \mathrm{M}$ phoyunnanin $\mathrm{E}$ (Figure $2 \mathrm{C}$ and $\mathrm{D}$ ). It is noteworthy that apoptotic cells (detected by annexin V-FITC/PI) in response to $50 \mu \mathrm{M}$ of phoyunnanin E comprised nearly $80 \%$, indicating the high apoptosis-inducing effect. In accordance with the results from Hoechst 33342 staining, Figure 2C shows that only minimal necrotic cells were observed in cells treated with phoyunnanin E, suggesting that the compound principally mediated cell death through apoptosis.

To support the above apoptotic activity of phoyunnanin E, the hallmarks of apoptosis, including activation of caspase-3 and caspase- 9 and cleavage of PARP were investigated in phoyunnanin E-treated cells. Western blot analysis showed that treatment of cells with phoyunnanin E markedly increased the level of cleaved PARP, while reducing the total intact PARP. Consistent with such results, expression of the active form of caspase- 3 and caspase- 9 was found to be significantly up-regulated in cells treated with phoyunnanin E (Figure 3).

Phoyunnanin E triggers apoptosis via p53 activation and suppression of survivin. It is well known that triggering apoptosis through the p53 pathway is a prime mechanism of action of several effective chemotherapeutic agents. Additionally, the suppression of the drug-resistant machinery of cancer cells can lead to enhanced susceptibility to apoptosis and treatment efficiency. An inhibitor of apoptosis, survivin, causes drug resistance in cancer cells by preventing apoptosis through inactivation of caspase-9 and caspase-3 (14). Since survivin as well as anti-apoptotic members of the BCL2 family of proteins are notorious as important chemotherapeutic resistance mediators $(10,21)$, we therefore investigated the mechanism of apoptosis induction of phoyunnanin $\mathrm{E}$ and its possible effects on BCL2, MCL1 and survivin.

Cells were treated with phoyunnanin $\mathrm{E}(0-50 \mu \mathrm{M})$ for $12 \mathrm{~h}$, and the cell lysates were subjected to western blot analysis for the detection of survivin and p53 protein. Figure 4A and B show that treatment of cells with phoyunnanin $\mathrm{E}$ reduced the expression of survivin. Importantly, phoyunnanin E increased 
A

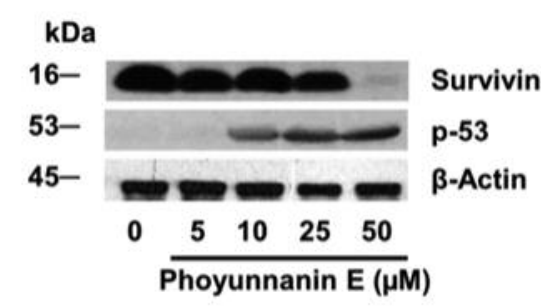

C

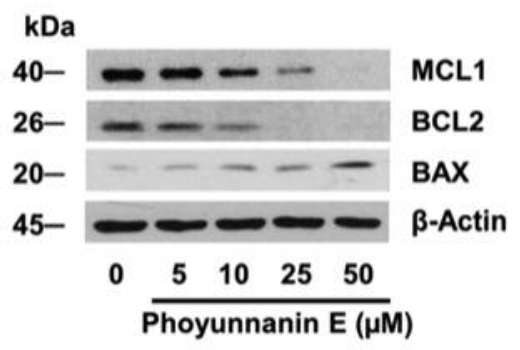

B
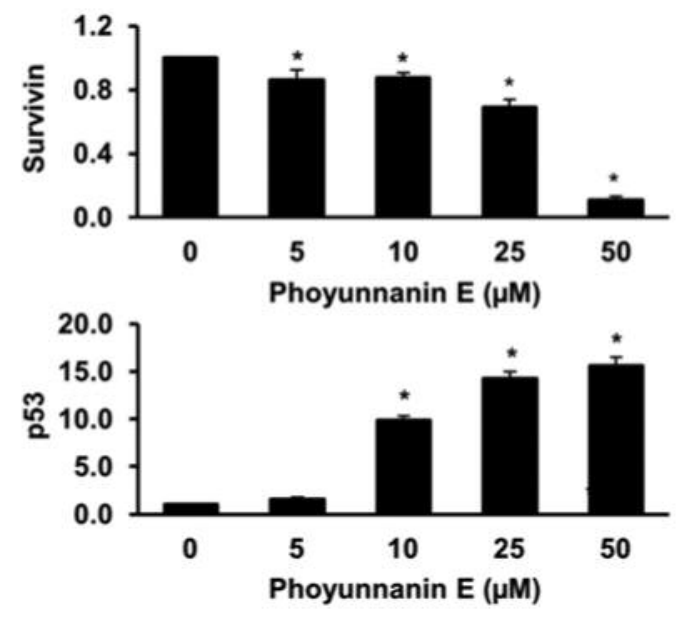

D
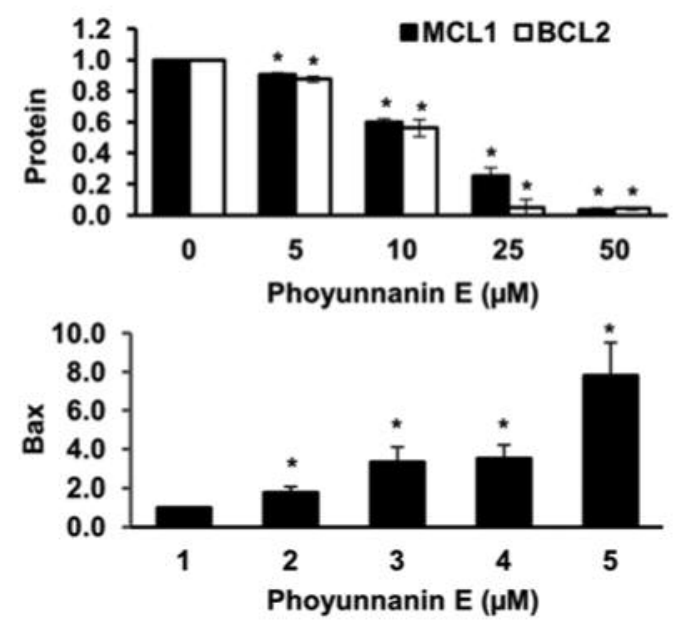

Figure 4. Phoyunnanin E induces apoptosis through accumulation of 553 and suppression of survivin. H460 cells were treated with phoyunnanin E for 12 h. A: Protein expression of survivin and 53 protein was determined by western blotting. B: Relative protein levels were quantified by densitometry. $C$ : The expression of anti-apoptotic proteins, MCL1 and BCL2, and pro-apoptotic protein, BAX, was determined by western blot assay. D: Relative protein levels were quantified by densitometry. Data represent the mean $\pm S D(n=3)$. *Significantly different at $p<0.05$ versus non-treated control.

the p53 level in the cells relative to the untreated control. The activation of $\mathrm{p} 53$ results in the increase of pro-apoptotic protein BAX and decrease of anti-apoptotic proteins, including MCL1 and BCL2 (5-7). Therefore, the expression of BAX, MCL1 and BCL2 were investigated following phoyunnanin E treatment. Expression of BAX was found to subsequently increase, while that of BCL2 and MCL1 was significantly down-regulated (Figure 4C and D). Interestingly, our results showed that the depletion of BCL2 and MCL1 may be partly independent of p53 driving, as the significant decrease of both proteins was observed in response to $5 \mu \mathrm{M}$ phoyunnanin $\mathrm{E}$, however, at such a concentration there was no detectable induction of p53 (Figure $4 \mathrm{~A}$ and $\mathrm{B}$ ). Taken together, these results indicate that phoyunnanin $\mathrm{E}$ induces apoptosis by activating the p53 pathway as well as suppressing anti-apoptotic proteins and survivin.
Apoptosis induction effect by phoyunnanin E in H23 human NSCLC-derived cells. Having shown the apoptosis-mediating effect of phoyunnanin E in NSCLC-derived H460 cells, we next confirmed such an effect of this compound in another lung cancer cell model. The H23 NSCLC-derived cells were similarly treated with phoyunnanin $\mathrm{E}$ at 0-50 $\mu \mathrm{M}$, after which apoptotic cells were investigated as described in the Materials and Methods. The results indicated that treatment of $\mathrm{H} 23$ cells with phoyunnanin E significantly increased the number of cells with condensed or fragmented nuclei (Figure 5A and B), and annexin V-FITC-positive cells (Figure 5C and D), confirming the apoptosis-inducing effect of phoyunnanin E. These data support our earlier findings in $\mathrm{H} 460$ cells to illustrate anticancer effect of phoyunnanin $\mathrm{E}$ in human NSCLC cells. 


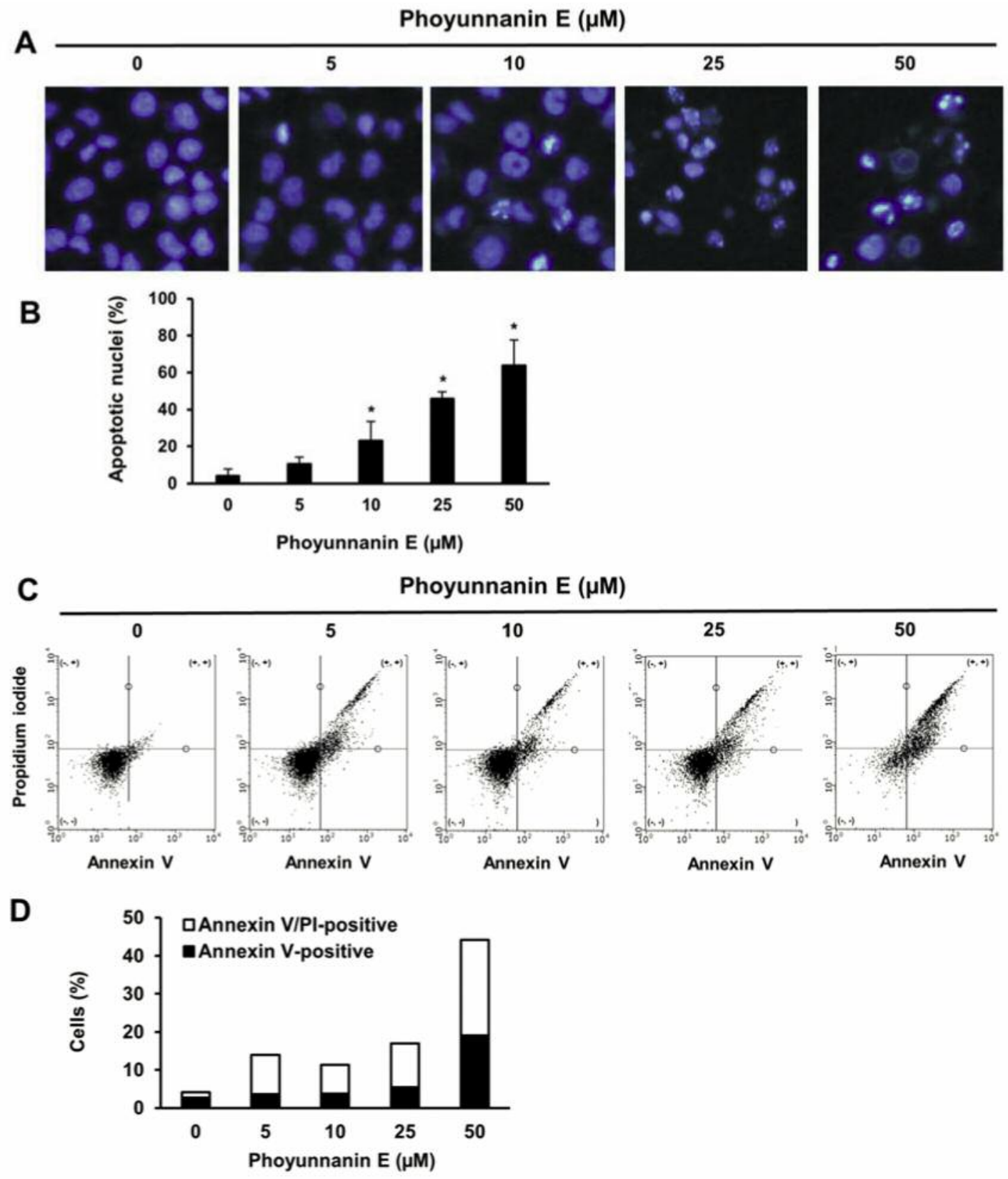

Figure 5. Phoyunnanin E induces apoptosis of H23 human NSCLC-derived cells. The cells were treated with phoyunnanin E for 24 h. A: Apoptotic cell death after phoyunnanin $E$ treatment was examined by Hoechst 33342 staining. B: The percentage of apoptotic nuclei in phoyunnanin E-treated cells was quantified. ${ }^{*} p<0.05$ versus non-treated control. C: Apoptotic and necrotic cells were determined by annexin V-fluorescein isothiocyanate and propidium iodide (PI) staining and detected by flow cytometry after phoyunnanin $E$ treatment. D: The percentage of annexin V-positive and annexin V/PI-positive cells was analyzed. Data represent the mean $\pm S D(n=3)$. *Significantly different at $p<0.05$ versus non-treated control.

\section{Discussion}

In pharmacological research, the discovery of more efficient therapeutic drug for cancer is continuously in need. Focusing on lung cancer, chemotherapy is a principle procedure in both primary and palliative care. Although cancer cells usually respond well at the beginning of chemotherapeutic treatment, efficacy declines due to attenuated response of the cancer cells to such therapy due to acquired resistance $(2,22)$. This leads to the need to increase the drug dosage, which frequently causes adverse effects. Patients with lung cancer, in particular NSCLC, often have metastasis at the time of first 


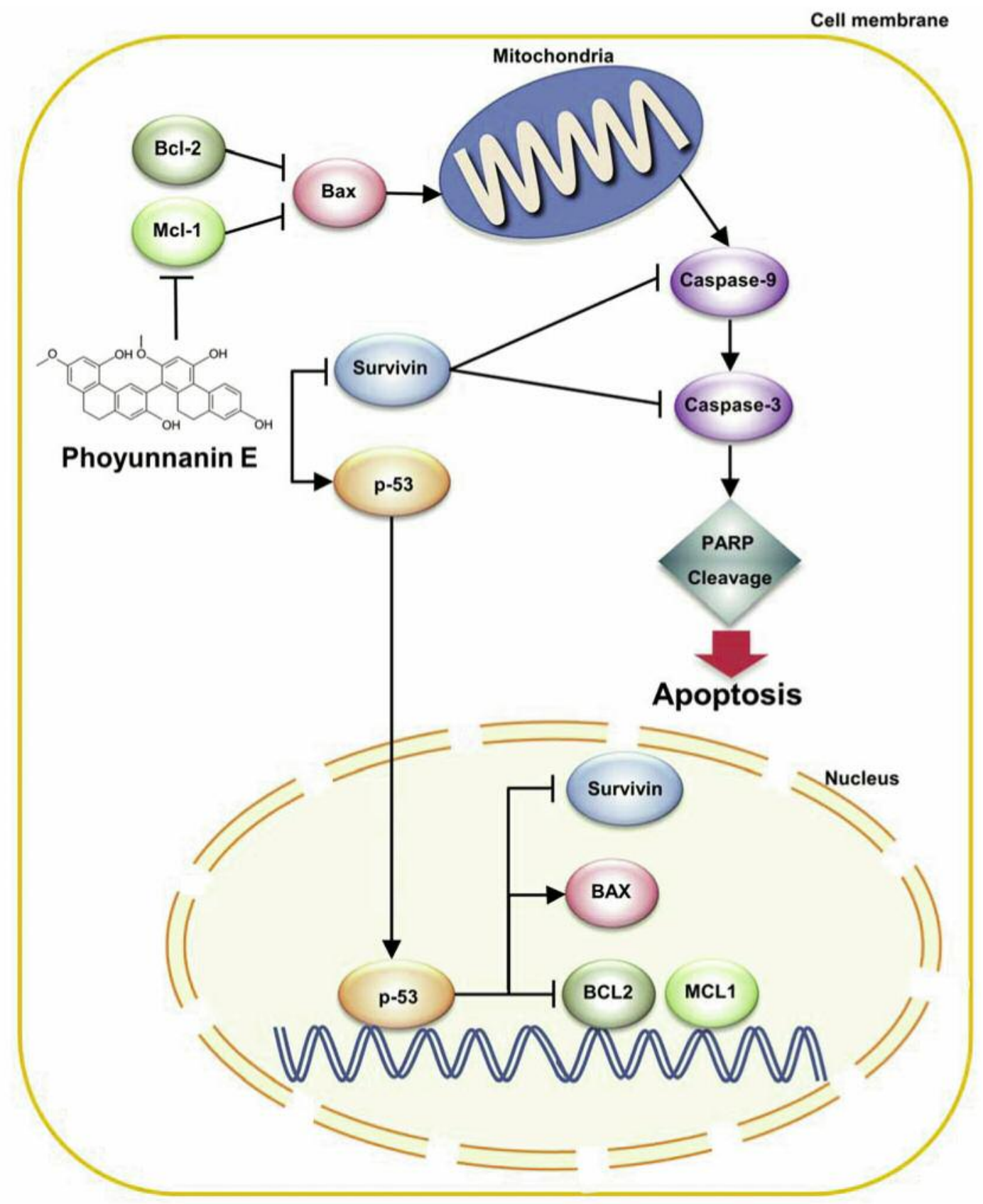

Figure 6. Schematic overview of the phoyunnanin E-induced apoptosis via p53-and survivin-dependent mechanisms. Phoyunnanin E induces apoptosis by activating $p 53$ and suppressing expression of survivin protein. The augmentation of p53 further reduces the expression of survivin and anti-apoptotic proteins, myeloid leukemia cell differentiation protein (MCL1) and B-cell lymphoma 2 (BCL2), while increases the expression of proapoptotic protein, $B c$-2-associated X protein (BAX). The imbalance between anti-apoptotic and pro-apoptotic proteins subsequently stimulates the caspase cascade with activation of caspase-9, and caspase-3, leading to apoptosis.

diagnosis, and these cells are intrinsically resist to anticancer drugs, making it more difficult to manage. Indeed, drug resistance of cancer cells is caused through several mechanisms attenuating apoptotic response. The reduction of apoptosis signals facilities proliferation and progression of cancer $(3,9)$. Numerous stress signals, including DNA damage, can activate the intrinsic pathway of apoptosis (8, $23,24)$. These events alter the integrity of the mitochondrial membrane, which is regulated by BCL2 family members (23$25)$. The balance between pro-apoptotic and anti-apoptotic 
proteins of the BCL2 family determines whether or not a cell will undergo apoptosis. The BCL2 family proteins include BAX, BCL2 and MCL1, which are upstream mediators of apoptosis controlling caspase activation $(8,23,24)$.

Here we have shown the effect of phoyunnanin $E$ in induction of $\mathrm{p} 53$-mediated apoptosis with the decrease of prosurvival proteins BCL2, MCL1, and survivin. The induction of apoptosis induced by phoyunnanin E was mainly due to p53 activation. As a consequence, we observed BCL2 and MCL1 down-regulation together with BAX increase in phoyunnanin E-treated cells (Figure 4). Additionally, we hypothesized that the compound at low concentration could directly suppress BCL2, MCL1, and survivin independently of p53 function, as it can significantly reduce the level of BCL2, MCL1, and survivin at $5 \mu \mathrm{M}$, at which p53 was not substantially activated (Figure 4). Regarding survivin, evidence has suggested that this protein plays a key role in mediating resistance to apoptosis $(9,26)$. It was also found that an elevated expression level of survivin was associated with poor prognosis and cancer progression (10). The suppression of survivin was suggested to be a possible way to improve response to radiation and chemotherapy $(27,28)$. Not only was phoyunnanin $\mathrm{E}$ found to be more potent than cisplatin and etoposide (Figure 1C), but it also caused less necrotic cell death, as indicated by PI staining, even when used at high concentrations (Figure $2 \mathrm{C}$ and D). It was shown that the widely prescribed anticancer drug cisplatin causes toxicity to renal tubular cells via non-specific induction of necrosis $(29,30)$. Hence, compounds with less induction of necrosis may cause lesser toxicity to normal cells.

In closing, we have shown that phoyunnanin $\mathrm{E}$ has a potent anticancer activity through p53-dependent induction of apoptosis and the suppression of drug resistance-related proteins (Figure 6). These findings may essentially benefit the development of this promising compound for the treatment of lung cancer.

\section{Conflicts of Interest}

The Authors declare that there are no conficts of interest in regard to this study. The Authors alone are responsible for the content and writing of this article.

\section{Acknowledgements}

This research was funded by Chulalongkorn University, CUGR_60_23_33_06. The Authors would like to thank Mr. Krich Rajprasit, a proofreader.

\section{References}

1 Ashworth A, Rodrigues G, Boldt G and Palma D: Is there an oligometastatic state in non-small cell lung cancer? A systematic review of the literature. Lung Cancer 82: 197-203, 2013.
2 Rotow J and Bivona TG: Understanding and targeting resistance mechanisms in NSCLC. Nat Rev Cancer 17: 637-658, 2017.

3 Fesik SW: Promoting apoptosis as a strategy for cancer drug discovery. Nat Rev Cancer 5: 876-885, 2005.

4 Wang X, Simpson ER and Brown KA: p53: Protection against tumor growth beyond effects on cell cycle and apoptosis. Cancer Res 75: 5001-5007, 2015.

5 Miyashita T, Krajewski S, Krajewska M, Wang HG, Lin HK, Liebermann DA, Hoffman B and Reed JC: Tumor suppressor p53 is a regulator of $B C L-2$ and $B A X$ gene expression in vitro and in vivo. Oncogene 9: 1799-1805, 1994.

6 Hemann MT and Lowe SW: The p53-BCL2 connection. Cell Death Differ 13: 1256-1259, 2006.

7 Pietrzak $M$ and Puzianowska-Kuznicka M: p53-Dependent repression of the human $M C L-1$ gene encoding an anti-apoptotic member of the BCL-2 family: The role of Sp1 and of basic transcription factor binding sites in the $M C L-1$ promoter. Biol Chem 389: 383-393, 2008.

8 Ouyang L, Shi Z, Zhao S, Wang FT, Zhou TT, Liu B and Bao JK: Programmed cell death pathways in cancer: A review of apoptosis, autophagy and programmed necrosis. Cell Prolif 45: 487-498, 2012.

9 Mohammad RM, Muqbil I, Lowe L, Yedjou C, Hsu HY, Lin LT, Siegelin MD, Fimognari C, Kumar NB, Dou QP, Yang H, Samadi AK, Russo GL, Spagnuolo C,Ray SK, Chakrabarti M, Morre JD, Coley HM, Honoki K, Fujii H, Georgakilas AG, Amedei A, Niccolai E, Amin A, Ashraf SS, Helferich WG, Yang X, Boosani CS, Guha G, Bhakta D, Ciriolo MR, Aquilano K, Chen S, Mohammed SI, Keith WN, Bilsland A, Halicka D, Nowsheen S and Azmi AS: Broad targeting of resistance to apoptosis in cancer. Semin Cancer Biol 35: S78-s103, 2015.

10 Huang W, Mao Y, Zhan Y, Huang J, Wang X, Luo P, Li LI, Mo D, Liu Q, Xu H and Huang C: Prognostic implications of survivin and lung resistance protein in advanced non-small cell lung cancer treated with platinum-based chemotherapy. Oncol Lett 11: 723-730, 2016.

11 Atikcan S, Unsal E, Demirag F, Koksal D and Yilmaz A: Correlation between survivin expression and prognosis in nonsmall cell lung cancer. Respir Med 100: 2220-2226, 2006.

12 Wang J, Liu Z, Zhang D, Liu R, Lin Q, Liu J, Yang Z, Ma Q, Sun D, Zhou $X$ and Jiang G: FL118, a novel survivin inhibitor, wins the battle against drug-resistant and metastatic lung cancers through inhibition of cancer stem cell-like properties. Am J Transl Res 9: 3676-3686, 2017.

13 Fischer M, Quaas M, Nickel A and Engeland K: Indirect p53dependent transcriptional repression of survivin, $C D C 25 C$, and $P L K 1$ genes requires the cyclin-dependent kinase inhibitor p21/CDKN1A and $C D E / C H R$ promoter sites binding the DREAM complex. Oncotarget 6: 41402-41417, 2015.

14 Mita AC, Mita MM, Nawrocki ST and Giles FJ: Survivin: key regulator of mitosis and apoptosis and novel target for cancer therapeutics. Clin Cancer Res 14: 5000-5005, 2008.

15 Chen CY, Yu ZY, Chuang YS, Huang RM and Wang TC: Sulforaphane attenuates EGFR signaling in NSCLC cells. J Biomed Sci 22: 38, 2015.

16 Chanvorachote $\mathrm{P}$, Chamni S, Ninsontia $\mathrm{C}$ and Phiboonchaiyanan PP: Potential anti-metastasis natural compounds for lung cancer. Anticancer Res 36: 5707-5717, 2016.

17 Sznarkowska A, Kostecka A, Meller K and Bielawski KP: Inhibition of cancer antioxidant defense by natural compounds. Oncotarget 8: 15996-16016, 2017. 
18 Sukphan P, Sritularak B, Mekboonsonglarp W, Lipipun V and Likhitwitayawuid K: Chemical constituents of Dendrobium venustum and their antimalarial and anti-herpetic properties. Nat Prod Commun 9: 825-827, 2014.

19 Petpiroon N, Sritularak B and Chanvorachote P: Phoyunnanin E inhibits migration of non-small cell lung cancer cells via suppression of epithelial-to-mesenchymal transition and integrin alpha-v and integrin beta-3. BMC Complement Altern Med 17: $553,2017$.

20 Phiboonchaiyanan PP and Chanvorachote P: Suppression of a cancer stem-like phenotype mediated by alpha-lipoic acid in human lung cancer cells through down-regulation of beta-catenin and Oct-4. Cell Oncol 40: 497-510, 2017.

21 Cheong HT, Xu F, Choy CT, Hui CWC, Mok TSK and Wong $\mathrm{CH}$ : Up-regulation of BCL2 in NSCLC with acquired resistance to EGFR-TKI. Oncol Lett 15: 901-907, 2018.

22 Ballestreri É, Simon D, de Souza AP, Grott CS, Nabinger DD, Dihl RR and Grivicich I: Resistance mechanism to cisplatin in NCI-H460 non-small cell lung cancer cell line: Investigating apoptosis, autophagy, and cytogenetic damage. Cancer Drug Resistance 1: 72-81, 2018.

23 Lopez J and Tait SW: Mitochondrial apoptosis: Killing cancer using the enemy within. Br J Cancer 112: 957-962, 2015.

24 Siddiqui WA, Ahad A and Ahsan H: The mystery of BCL2 family: BCL2 proteins and apoptosis: An update. Arch Toxicol 89: 289-317, 2015.

25 Barille-Nion S, Bah N, Vequaud E and Juin P: Regulation of cancer cell survival by BCL2 family members upon prolonged mitotic arrest: Opportunities for anticancer therapy. Anticancer Res 32: 4225-4233, 2012.
26 Jiang L, Luo RY, Yang J and Cheng YX: Knockdown of survivin contributes to antitumor activity in cisplatin-resistant ovarian cancer cells. Mol Med Rep 7: 425-430, 2013.

27 Lu B, Mu Y, Cao C, Zeng F, Schneider S, Tan J, Price J, Chen J, Freeman M and Hallahan DE: Survivin as a therapeutic target for radiation sensitization in lung cancer. Cancer Res 64: 28402845, 2004

28 Garg H, Suri P, Gupta JC, Talwar GP and Dubey S: Survivin: A unique target for tumor therapy. Cancer Cell Int 16: 49, 2016.

29 Miller RP, Tadagavadi RK, Ramesh G and Reeves WB: Mechanisms of Cisplatin nephrotoxicity. Toxins 2: 2490-2518, 2010.

30 Sancho-Martinez SM, Piedrafita FJ, Cannata-Andia JB, LopezNovoa JM and Lopez-Hernandez FJ: Necrotic concentrations of cisplatin activate the apoptotic machinery but inhibit effector caspases and interfere with the execution of apoptosis. Toxicol Sci 122: 73-85, 2011.
Received August 5, 2018

Revised September 5, 2018

Accepted October 5, 2018 